\title{
MESENTERIC THROMBOSIS IN PATIENT VICTIM OF BLUNT ABDOMINAL TRAUMA WITH FATAL OUTCOME
}

\author{
Trombose mesentérica em vítima de trauma abdominal fechado com desfecho fatal \\ Iwan Augusto COLLAÇO, Allan Cezar DIORIO, Adonis NASR, Fernanda Cristina da SILVA, \\ William Augusto Casteleins CECÍLIO, Rodolfo Cardoso de TOLEDO-FILHO
}

From the Serviço de Cirurgia Geral, Hospital do Trabalhador, Universidade Federal do Paraná, Curitiba, PR, Brasil.

HEADINGS - Abdominal trauma. Mesentery. Thrombosis.

Correspondência:

Adonis Nasr,

e-mail adonis@bighost.com.br

Fonte de financiamento: não há

Conflito de interesses: não há

Recebido para publicação: 27/05/2009

Aceito para publicação: 11/12/2009

DESCRITORES - Trauma abdominal. Mesentério. Trombose.
ABSTRACT - Background - Mesenteric thrombosis related to trauma is an uncommon entity and has poor prognosis when have low flow and hemorrhagic shock. It usually presents with a challenging diagnosis and high mortality rates, despite appropriate treatment. Case report - Patient with blunt trauma was admitted and initial treatment, complementary exams showed ribs and humerus fractures. Computerized tomography showed aerial distension in small bowels along with gastric stasis and hidropneumothorax. The patient had hypotension during clinical observation and cardiopulmonary arrest, responding to reanimation. Taken to surgery for damage control, it was found extensive necrosis of right colon, which was excised and performed primary anastomosis. He was admitted in the intensive care unit, evolving with oliguria, miosis, convulsion, and pulseless electric activity, dying three days after hospital admission. Conclusion - Although uncommon, mesenteric ischemia with venous thrombosis might be secondary to systemic hypotension, frequently followed by fatal outcomes.

RESUMO - Introdução - Trombose mesentérica, relacionada a trauma é entidade incomum, com pobre prognóstico quando seguida de estados de baixo fluxo e choque hipovolêmico. Geralmente apresenta-se com quadro de difícil diagnóstico, cuja mortalidade é elevada a despeito de tratamento adequado. Relato do caso - Paciente submetido a trauma, após admissão hospitalar e atendimento inicial, exames radiológicos demonstraram fratura de costela e úmero. Tomografia computadorizada evidenciou distensão aérea em intestino delgado associada à estase gástrica e hidropneumotórax. O paciente evoluiu com hipotensão durante - período de observação clínica e parada cardiorrespiratória que respondeu à reanimação. Levado para operação para controle de danos, encontrou-se extensa necrose de cólon ascendente. Realizou-se hemicolectomia direita com íleotransversostomia. Levado à unidade de terapia intensiva, evoluiu com oligúria, miose, convulsão e atividade elétrica sem pulso, falecendo três dias após dar entrada no hospital. Conclusão - Embora incomum, isquemia mesentérica com trombose venosa pode ser secundária à hipotensão sistêmica, com desfecho fatal.
$\mathrm{M}$ esenteric thrombosis is an uncommon entity, with diagnosis primarily clinical, having pain as a hallmark symptom. The main etiological causes are intrinsic anticoagulant deficiencies, infection and trauma ${ }^{2}$. In the case of trauma, the resulting ischemic complications are associated with hemorrhagic shock, leading to acute renal, pulmonary, and hepatic failure, culminating with death ${ }^{4}$.

\section{CASE REPORT}

A 45 years-old male was brought in to the Advanced Trauma Life Support Unit in the Emergency Service of the Hospital do Trabalhador, victim of motor vehicle accident. In the initial exam, he presented chest contusion associated with reduction in breath sounds in the base of the right lung, besides, 
alcoholic breath. Vitals were normal at this point, with a RTS (Revised Trauma Score) of 7,84 points, and 14 in the Glasgow Coma Scale.

The patient went through routine radiological exams, with multiple right rib fractures and a closed fracture of the humerus. After analgesia, intravenous saline hydration, he kept on referring diffuse abdominal pain. Computerized tomography (CT) was performed and aerial distention of small bowels was found, along with gastric stasis and a discreet hydropneumothorax in the right chest. The patient was maintained in repose for observation during the night, presenting a few episodes of vomiting and transitory blood pressure falling culminating with cardiorespiratory arrest after two hours from initial treatment. Resuscitation was promptly initiated, also using catecholamines, tracheal intubation and mechanic ventilation.

In the following morning diagnostic peritoneal lavage was performed, resulting a dark blood-like fluid after what exploratory laparotomy was indicated. A rapid preoperative anesthetic evaluation classified the patient as ASA III (American Society of Anesthesiologist classification). Blood gasometry collect at that moment was compatible with mixed acidosis $(\mathrm{pH}=6,924)$.

Surgical exploration revealed the presence of 300 $\mathrm{mL}$ of free liquid in the abdominal cavity, and extensive necrosis of approximately $90 \mathrm{~cm}$ of intestinal loops, implicating terminal ileum and descending colon. Right hemicolectomy with ileumtransverse anastomosis was performed. It was also found laceration of the inferior pole of spleen, and a small bleeding from portal vein, immediately sutured. The abdominal cavity was covered with a Bogota bag for temporary closure, leaving five bandages inside the abdomen for hemostasis. During surgery, three units of erythrocytes concentrate and three units of fresh frozen plasma were infused. In the afternoon, the patient was admitted in the intensive care unit, sedated and hemodynamically unstable.

After the surgical procedure, CT images were discussed with radiologist, that reported: presence of gas inside portal vessels, intramural air in distal small bowels (suggesting the occurrence of severe ischemic process), and a thin layer of perihepatic liquid (Figures 1 and 2).

During the next two days, invasive mechanic ventilation was sustained, along with the prescription of catecholamines, transfusion of six extra units of erythrocytes and 10 units of platelets. The patient evolved with oliguria, miosis, and convulsion, presenting pulseless electric activity and other two cardiorespiratory arrests. Death was called three days after in-hospital admission, before a new laparotomy surgery for damage control could be executed.

\section{DISCUSSION}

The occurrence of shock-associated right colon necrosis, presented in this case, is little reported in literature. In a case report of three similar cases, all

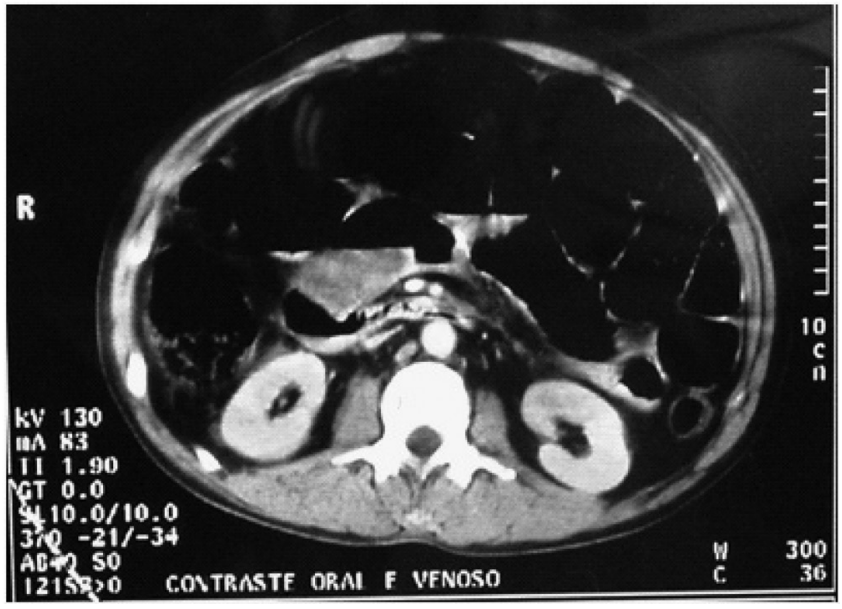

FIGURE 1- Abdominal CT with oral and venous contrast showing aerial distention of small bowel loops, along with intramural air and gaseous embolism of portal vein

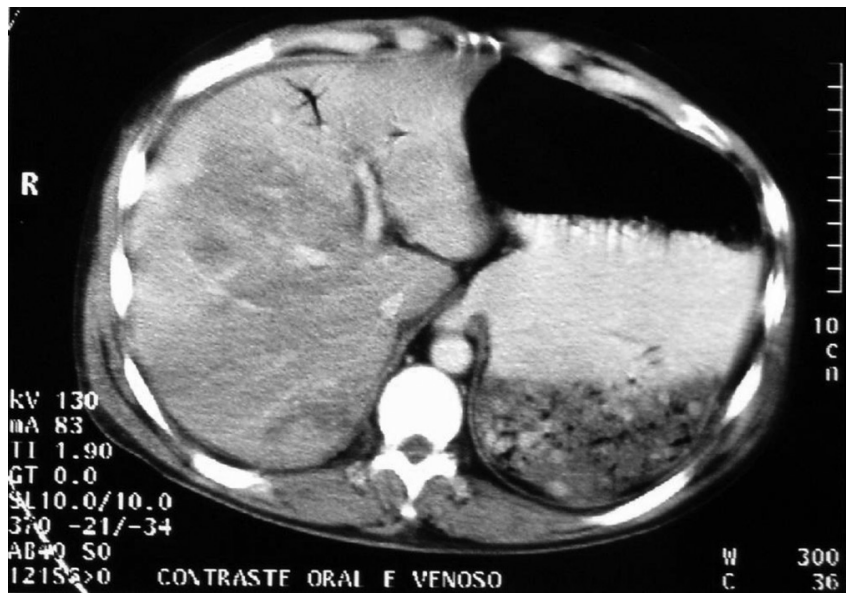

FIGURE 2 - Abdominal CT showing free liquid in the cavity, and a thin layer of perihepatic liquid

patients suffered a period of hypotension after injury 4 . Diagnosis and operation took place within two days of initial trauma, resulting in right colectomy and primary anastomosis without complication. In all three cases, pathologic examination showed ischemic necrosis, but no evidence of vascular thrombosis or embolic occlusion of the mesenteric vessels. The etiology of this type of ischemic colitis is not clear, but seems to represent a form of non occlusive mesenteric ischemia.

A separate study, covering eight years of observation, identified 13 patients treated for superior mesenteric vascular injury secondary to blunt abdominal trauma ${ }^{1}$. Six patients presented in profound shock, two with cardiopulmonary arrest. Mortality rate was $57 \%$ in this series, primarily due to massive acute hemorrhage.

Contrast-enhanced $\mathrm{CT}$ is at present considered the examination of choice for acute mesenteric vein occlusion in non-traumatic situations ${ }^{3}$. Emergency 
situations, on the other hand, should have diagnosis based on clinical suspicious at the secondary exam of patients, after in-hospital admission.

\section{CONCLUSION}

It is emphasized the importance for the attending physician to bear in mind that mesenteric ischemia and venous thrombosis might be secondary to states of reduced systemic blood flow. Although uncommon, this situation is frequently followed by fatal outcomes, embracing the field of interest of both the general and vascular surgeon.

\section{REFERENCES}

1. Courcy PA, Brotman S, Oster-Granite ML, Soderstrom CA, Siegel $\mathrm{JH}$, Cowley RA. Superior mesenteric artery and vein injuries from blunt abdominal trauma. J Trauma 1984;24(9):843-5.

2. Geyer DE, Krenning LE. Mesenteric venous thrombosis: a case report. J Fam Pract 1993;36(4):454-6.

3. Haage $P$, Krings $T$, Schmitz-Rode T. Nontraumatic vascular emergencies: imaging and intervention in acute venous occlusion. Eur Radio. 2002;12(11):2627-43.

4. Ludwig KA, Quebbeman EJ, Bergstein JM, Wallace JR, Wittmann $\mathrm{DH}$, Aprahamian C. Shock-associated right colon ischemia and necrosis. J Trauma 1995;39(6):1171-4. 